\title{
The Role of Steroid Hormones in the Development of Intrahepatic Cholestasis of Pregnancy
}

\author{
A. PAŘÍZEK ${ }^{1}$, M. DUŠKOVÁ ${ }^{2}$, L. VÍTEK ${ }^{3,4}$, M. ŠRÁMKOVÁ ${ }^{2}$, M. HILL ${ }^{2}$, \\ K. ADAMCOVÁ ${ }^{1}$, P. ŠIMJÁK ${ }^{1}$, A. ČERNÝ ${ }^{1}$, Z. KORDOVÁ ${ }^{1}$, H. VRÁBLÍKOVÁ ${ }^{1}$, \\ B. BOUDOVÁ ${ }^{1}$, M. KOUCKÝ ${ }^{1}$, K. MALÍČKOVÁ ${ }^{3}$, L. STÁRKA $^{2}$
}

${ }^{1}$ Department of Obstetrics and Gynecology of the First Faculty of Medicine and General Teaching Hospital, Prague, Czech Republic, ${ }^{2}$ Institute of Endocrinology, Prague, Czech Republic, ${ }^{3}$ Institute of Medical Biochemistry and Laboratory Diagnostics, First Faculty of Medicine, Charles University in Prague, Prague, Czech Republic, ${ }^{4}$ Fourth Department of Internal Medicine, First Faculty of Medicine, Charles University in Prague, Prague, Czech Republic

Received June 22, 2015

Accepted July 7, 2015

\section{Summary}

Intrahepatic cholestasis of pregnancy (ICP) is a disorder of liver function, commonly occurring in the third trimester but sometimes also as soon as the end of the second trimester of pregnancy. Symptoms of this disorder include pruritus, plus abnormal values of bile acids and hepatic transaminases. After birth, symptoms disappear and liver function returns to normal. Though ICP is relatively non-complicated and often symptomatically mild from the point-of-view of the mother, it presents a serious risk to the fetus, making this disease the subject of great interest. The etiology and pathogenesis of ICP is multifactorial and as yet not fully elucidated. Hormonal factors likely play a significant role, along with genetic as well as exogenous factors. Here we summarize the knowledge of changes in steroid hormones and their role in the development of intrahepatic cholestasis of pregnancy. In addition, we consider the role of exogenous factors as possible triggers of steroid hormone changes, the relationship between metabolic steroids and bile acids, as well as the combination of these factors in the development of ICP in predisposed pregnant women.

\section{Key words}

Allopregnanolone - epiallopregnanolone - 17ß-estradiol • Farnesoid X receptor $\bullet$ Selenium - Leaky gut in pregnancy • Cholestasis

\section{Corresponding author}

M. Dušková, Institute of Endocrinology, Národní 8, 11694 Prague 1, Czech Republic. E-mail: mduskova@endo.cz

\section{Introduction}

Intrahepatic cholestasis of pregnancy (ICP) is a relatively uncommon complication during pregnancy. ICP was first described by Ahlfeld (1883) who described itching and jaundice in the last trimester of pregnancy that subsequently disappeared after birth. The prevalence depends on geographic location, with the highest per capita reported by pregnant women in Chile and Bolivia (up to $14 \%$ ); a high prevalence has also been reported from southern Asia and other South American countries. In Europe, less than $1 \%$ of pregnant women are affected (Pusl and Beuers 2007), and the prevalence in the Czech Republic is about $0.86 \%$ (Binder et al. 2007). ICP is caused by a liver function disorder, occurring during pregnancy usually during the third trimester but sometimes also as soon as the end of the second trimester. The disease is characterized by the presence of pruritus plus abnormal values of bile acids and hepatic transaminases, and has undesirable effects on the fetus. Icterus is not always present. After birth the disease symptoms disappear and liver function returns to normal. Though ICP is a relatively non-complicated and often 
symptomatically mild disease from the point-of-view of the mother, it presents a serious risk to the fetus (Pusl and Beuers 2007).

It is this serious risk of damage to the fetus that makes ICP the subject of great interest. ICP increases the risk of premature birth, the excretion of meconium to the amniotic fluid, respiratory distress syndrome and sudden fetal death. Precise pathophysiologic mechanisms leading to fetal complications still remain the subject of study, but it is believed, that bile acids play a key role. These serious complications do not, however, correlate with the clinical and laboratory findings of the mother, and so it is very difficult to predict when the fetus is at risk (Šimják et al. 2015). Changes in steroid hormones may also affect the development of this disorder. Higher levels of cortisol and dehydroepiandrosterone sulfate have been reported in fetuses of mothers with ICP (Wang et al. 2011). Increased levels of serum bile acids lower the expression of 11ß-hydroxysteroid dehydrogenase type 2, which protects the fetus from exposure to high cortisol levels in the mother (Martineau et al. 2014).

The etiology and pathogenesis of ICP is multifactorial, and as yet not fully elucidated. Hormonal factors most likely play a significant role (Glantz et al. 2008, Reyes 2008), along with genetic as well as exogenous factors (Glantz et al. 2004). Genetic studies have shown a genetic predisposition to this disorder, and recent research has focused on searching for mutations in genes coding for transport proteins of bile excretion.

Patients with ICP have been described as having higher gastrointestinal permeability ("leaky gut"), which could lead to the increased absorption of bacterial endotoxins (Reyes et al. 2006). Other studies have described the influence of dietary factors (such as dietary selenium deficiencies) (Reyes et al. 2000), seasonal factors (with higher incidence in winter months), and the dependence of prevalence on geographic location (Lammert et al. 2000).

Some of the fundamental characteristics of this disorder indicate that placental hormones have a significant effect on the appearance of ICP. The disorder is most common during the third trimester, when levels of pregnancy hormones produced by the placenta are highest. This is supported by the fact that the incidence is higher in multiple pregnancies, which is associated with higher levels of pregnancy hormones compared to singleton pregnancies (Glantz et al. 2008, Lammert et al. 2000, Reyes et al. 2000, Reyes 2008). ICP disappears after birth, when hormone levels return to normal.

\section{Steroids and ICP}

The association of ICP with the third trimester has led many researchers to study changes in steroidogenesis in women with ICP, with findings of lower levels of estrogen and dehydroepiandrosterone sulfate (Leslie et al. 2000). Most studies concur that there are also higher metabolites of progesterone found in patients with ICP, with the main changes occurring in their sulfates (Meng et al. 1997c, Reyes and Sjövall 2000). The question remains, however, if this is a result of a disorder in liver function or whether these metabolites play a role in the development of ICP. The higher levels of progesterone metabolites may be just a reflection of damaged liver cell function, and it is difficult to decipher which of them may be responsible for this damage.

After treatment with ursodeoxycholic acid (UDCA) and improvement in liver parameters, the steroid spectrum also improves (Meng et al. 1997a,b, Glantz et al. 2008). These studies also demonstrate that UDCA improves the excretion of progesterone metabolites, which gives support to the theory that increased steroids are a result of liver cell damage. However, in a study on a large group of healthy women with asymptomatic hypercholanemia, Pascual et al. (2002) found decreased progesterone levels and higher levels of its metabolites, which could support the hypothesis of the primary role of steroids in the development of ICP. Some authors believe that patients with ICP have a selective defect in the excretion of steroid metabolites to the bile that only affects sulfate secretion. At the same time, there is speculation about the role of $3 \alpha$-steroid dehydrogenases in the development of ICP (Reyes and Sjövall 2000).

The role of estrogen in the onset of ICP is connected to its role in the development of estrogeninduced cholestasis, which also occurs in patients with ICP in their history if they are given estrogen. This indicates the possible similar basis of these disorders, though it is necessary to emphasize the significant differences and not necessarily apply knowledge of one disorder to the other. When giving synthetic estrogen, the chemical molecular structure can also play a specific role that might not be relevant for natural steroids. Another aspect is the transfer of knowledge gained from animal models, since there are large inter-species differences in steroidogenesis. In mouse models, norethistreone and other C17 $\alpha$-substituted steroids (methyltestosterone, oxymetholone, and northandrolone) can cause intrahepatic cholestasis, but neither testosterone 
propionate, progesterone nor $17 \beta$-estradiol have this effect. In contrast to mouse models, in rats not even high doses of norethisterone have a cholestatic effect (Imai and Hayashi 1970).

\section{The farnesoid $X$ receptor}

The farnesoid $X$ receptor (FXR) is associated with the homeostasis of bile acids and protects the liver from cholestasis. Bile acids are ligands of this receptor. Chenodeoxycholic acid has been shown to be the strongest ligand in vitro. FXR is also activated by lithocholic acid and deoxycholic acid. Activated FXR directly induces the expression of nuclear receptors that inhibit the biosynthesis of bile acids (inhibit the sodium taurocholate cotransporter peptide) that is responsible for the transport of bile acids from the lumen to hepatocytes, and at the same time induces the expression of the bile salt export pump (the main transporter of bile from the liver) (Rizzo et al. 2005).

Levels of epiallopregnanolone sulfate are higher during ICP. This progesterone metabolite is a partial agonist of FXR, and this is likely one of the possible mechanisms connecting progesterone metabolites to the development of ICP (Abu-Hayyeh et al. 2013). The farnesoid $\mathrm{X}$ receptor is also influenced by the estrogen receptor $\alpha(\mathrm{ER}-\alpha)$, which is able to inhibit FXR, that leads to the expression of pro-cholestatic genes (Milona et al. 2010).

\section{Bile salt export pump}

The bile salt export pump (Bsep) is responsible for the secretion of bile acids, and is a rate-limiting step in enterohepatic circulation. A 1331T $>$ C Bsep polymorphism has been shown to increase sensitivity to the development of ICP (Meier et al. 2008).

In animal models, it has been demonstrated that some estrogen and progesterone metabolites are able to inhibit Bsep (Vallejo et al. 1996), though progesterone itself does not (Byrne et al. 2002). Animal models have also shown that the dynamic transcription of Bsep is inversely correlated with serum levels of $17 \beta$-estradiol before, during, and after gestation. Transrepression of Bsep by $17 \beta$-estradiol occurs through the interaction between FXR and ER- $\alpha$ (Song et al. 2014). In subsequent studies these authors demonstrated that $17 \beta$-estradiol decreases the expression of Bsep through the lowering of the peroxisome proliferator-activated receptor- $\gamma$ coactivator-1, with a simultaneous decrease in nuclear receptors of co-repressors of Bsep promotors. They also identified the domain of ER- $\alpha$ responsible for transrepression of Bsep through interaction with FXR (Chen et al. 2015). Mapping these interactions between steroids and the metabolism of bile acids helps us better understand the pathophysiology of ICP.

\section{Sodium taurocholate cotransporter peptide}

Allopregnanolone sulfate and epiallopregnanolone sulfate have been shown to inhibit the uptake of taurocholate in hepatocytes, and this inhibition is dose dependent. During pregnancy these hormones reach levels that are necessary for this inhibition (AbuHayyeh et al. 2010). This is another mechanism that helps explain the role of progesterone metabolites in the development of ICP.

\section{Other nuclear receptors}

FXR is the main regulator of the homeostasis of bile acids, and together with other nuclear receptors such as the constitutive androstane receptor (CAR) and pregnane $\mathrm{X}$ receptor (PXR) that act as sensors of toxic products, play a role in the metabolism of bile acids (Kakizaki et al. 2011). Polymorphisms of PXR are associated with ICP (Castaño et al. 2010). The PXR agonist rifampicin has been successfully used to treat serious ICP in combination with ursodeoxycholic acid, when therapy with this drug alone was non-effective (Geenes et al. 2015).

\section{Selenium}

Several exogenous factors are also associated with the development of ICP. One of these is lowered selenium levels (Kauppila et al. 1986, Ribalta et al. 1995, Reyes et al. 2000). Low selenium levels in patients with ICP have been connected to lower activity of selenoenzyme glutathion peroxidase (Kauppila et al. 1986, Ribalta et al. 1995), which is a major antioxidant. Decreasing this enzyme could contribute to the onset of ICP through liver cells being unable to withstand oxidative damage.

However, the relationship between selenium levels and steroids is also interesting. Behne et al. (1976) demonstrated that high steroid levels during gestation in rats lowered the levels of selenium. A subsequent study showed lowered glutathione peroxidase in gravid compared to nulliparous rats (Behne et al. 1978). Lowered selenium levels found in women with ICP could be a secondary effect of higher steroid levels compared to 
healthy pregnant women.

The effects of the lowered selenium levels that might be caused by higher steroid levels during pregnancy are likely to be more highly expressed in regions with a selenium deficit, where lowered activity of glutathione peroxidase might be more apparent. This could help explain the geographic differences in the prevalence of ICP, as well as seasonal differences that might be influenced by changes in diets that in turn affect the amount of selenium ingested as well as its absorption. This theory is supported by the finding of a recent lower prevalence of ICP in Chile, with concurrently higher levels of dietary selenium. At the same time, a lower incidence of ICP in pregnant women during summertime is associated with higher dietary selenium levels in summer (Reyes et al. 2000).

Some studies have shown that the relationship between selenium and progesterone are likely not oneway, though other studies have not supported this. Supplementation of selenium leads to higher levels of progesterone in gravid Holstein heifers (Kamada et al. 2014), and changes of selenium in the diet of gravid sheep influences the levels of progesterone (Lekatz et al. 2010). However, these findings were not confirmed in later larger studies on sheep, which only found progesterone levels being influenced by nutrient restriction (Vonnahme et al. 2013, Lemley et al. 2014).

\section{Leaky gut}

Another exogenous factor implicated in the development of ICP is increased gastrointestinal permeability (leaky gut). Reyes et al. (2006) found that leaky gut may play a role in the pathogenesis of ICP, with increased absorption of bacterial endotoxins influencing the enterohepatic circulation of cholestatic metabolites of steroids and bile acids.

Levels of progesterone itself are lower in patients with ICP, in contrast to its metabolites. Tremellen et al. (2014) described a negative correlation between levels of a bacterial endotoxin (lipopolysaccharide) and progesterone in women treated for infertility. In experimental models using ovarian theca cells from cow ovaries, lowered production of progesterone was demonstrated through the downregulation of steroidogenesis enzymes by lipopolysaccharide (Magata et al. 2014a) and peptidoglycan (Magata et al. 2014b). The effect of endotoxins on steroidogenesis could be one factor influencing changes in steroid production, which may then lead to the onset of ICP in predisposed pregnant women. This complex pathway might represent one of the possible pathophysiological mechanisms in the development of ICP. Therefore, understanding the influences of exogenous factors such as selenium deficits and endotoxins on the development of ICP could lead to new therapeutic possibilities.

\section{Conclusion}

Intrahepatic cholestasis of pregnancy usually develops during the third trimester, indicating that steroid hormones may play a role in its onset. Recent studies have shown that $17 \beta$-estradiol and progesterone metabolites are able to influence the metabolism of bile acids at various levels. Changes in their levels induced by a combination of external factors (such as endotoxins and selenium deficiencies) and genetic predisposition may help explain the development of ICP.

\section{Conflict of Interest}

There is no conflict of interest.

\section{Acknowledgements}

The study was supported by grant IGA MZ CR NT 12211-5.

\section{References}

ABU-HAYYEH S, MARTINEZ-BECERRA P, SHEIKH ABDUL KADIR SH, SELDEN C, ROMERO MR, REES M, MARSCHALL HU, MARIN JJ, WILLIAMSON C: Inhibition of Na+-taurocholate Co-transporting polypeptide-mediated bile acid transport by cholestatic sulfated progesterone metabolites. J Biol Chem 285: 16504-16512, 2010.

ABU-HAYYEH S, PAPACLEOVOULOU G, LÖVGREN-SANDBLOM A, TAHIR M, ODUWOLE O, JAMALUDIN NA, RAVAT S, NIKOLOVA V, CHAMBERS J, SELDEN C, REES M, MARSCHALL HU, PARKER MG, WILLIAMSON C: Intrahepatic cholestasis of pregnancy levels of sulfated progesterone metabolites inhibit farnesoid X receptor resulting in a cholestatic phenotype. Hepatology 57: 716-726, 2013. 
AHLFELD F: Berichte und Arbeiten aus der Geburtshilflich-Gynaekologischen Klinik zu Giessen 1881-1882. Grunow FW (ed.), Leipzig, 1883, p. 148.

BEHNE D, ELGER W, SCHMELZER W, WITTE M: Effects of sex hormones and of pregnancy on the selenium metabolism. Bioinorg Chem 5: 199-202, 1976.

BEHNE D, VON BERSWORDT-WALLRABE R, ELGER W, WOLTERS W: Glutathione peroxidase in erythrocytes and plasma of rats during pregnancy and lactation. Experientia 34: 986-987, 1978.

BINDER T, ZIMA T, VÍTEK L: Biochemical parameters of the intrahepatic cholestasis of pregnancy (in Czech). Čes Gynek 72: 90-94, 2007.

BYRNE JA, STRAUTNIEKS SS, MIELI-VERGANI G, HIGGINS CF, LINTON KJ, THOMPSON RJ: The human bile salt export pump: characterization of substrate specificity and identification of inhibitors. Gastroenterology 123: 1649-1658, 2002.

CASTAÑO G, BURGUEÑO A, FERNÁNDEZ GIANOTTI T, PIROLA CJ, SOOKOIAN S: The influence of common gene variants of the xenobiotic receptor (PXR) in genetic susceptibility to intrahepatic cholestasis of pregnancy. Aliment Pharmacol Ther 31: 583-592, 2010.

CHEN Y, VASILENKO A, SONG X, VALANEJAD L, VERMA R, YOU S, YAN B, SHIFFKA S, HARGREAVES L, NADOLNY C, DENG R: Estrogen and estrogen receptor- $\alpha$-mediated transrepression of bile salt export pump. Mol Endocrinol 29: 613-626, 2015.

GEENES V, CHAMBERS J, KHURANA R, SHEMER EW, SIA W, MANDAIR D, ELIAS E, MARSCHALL HU, HAGUE W, WILLIAMSON C: Rifampicin in the treatment of severe intrahepatic cholestasis of pregnancy. Eur J Obstet Gynecol Reprod Biol 189: 59-63, 2015.

GLANTZ A, MARSCHALL HU, MATTSSON LA: Intrahepatic cholestasis of pregnancy: relationship between bile acid levels and fetal complication rates. Hepatology 40: 467-474, 2004.

GLANTZ A, REILLY SJ, BENTHIN L, LAMMERT F, MATTSSON LA, MARSCHALL HU: Intrahepatic cholestasis of pregnancy: amelioration of pruritus by UDCA is associated with decreased progesterone disulphates in urine. Hepatology 47: 544-551, 2008.

IMAI K, HAYASHI Y: Steroid-induced intrahepatic cholestasis in mice. Jpn J Pharmacol 20: 473-481, 1970.

KAKIZAKI S, TAKIZAWA D, TOJIMA H, HORIGUCHI N, YAMAZAKI Y, MORI M: Nuclear receptors CAR and PXR; therapeutic targets for cholestatic liver disease. Front Biosci (Landmark Ed) 16: 2988-3005, 2011.

KAMADA H, NONAKA I, TAKENOUCHI N, AMARI M: Effects of selenium supplementation on plasma progesterone concentrations in pregnant heifers. Anim Sci J 85: 241-246, 2014.

KAUPPILA A, KORPELA H, MÄKILÄ UM, YRJÄNHEIKKI E: Low serum selenium concentration and glutathione peroxidase activity in intrahepatic cholestasis of pregnancy. Br Med J (Clin Res Ed) 294: 150-152, 1987.

LAMMERT F, MARSCHALL HU, GLANTZ A, MATERN S: Intrahepatic cholestasis of pregnancy: molecular pathogenesis, diagnosis and management. J Hepatol 33: 1012-1021, 2000.

LESLIE KK, REZNIKOV L, SIMON FR, FENNESSEY PV, REYES H, RIBALTA J: Estrogens in intrahepatic cholestasis of pregnancy. Obstet Gynecol 95: 372-376, 2000.

LEKATZ LA, CATON JS, TAYLOR JB, REYNOLDS LP, REDMER DA, VONNAHME KA: Maternal selenium supplementation and timing of nutrient restriction in pregnant sheep: effects on maternal endocrine status and placental characteristics. J Anim Sci 88: 955-971, 2010.

LEMLEY CO, MEYER AM, NEVILLE TL, HALLFORD DM, CAMACHO LE, MADDOCK-CARLIN KR, WILMOTH TA, WILSON ME, PERRY GA, REDMER DA, REYNOLDS LP, CATON JS, VONNAHME KA: Dietary selenium and nutritional plane alter specific aspects of maternal endocrine status during pregnancy and lactation. Domest Anim Endocrinol 46: 1-11, 2014.

MAGATA F, HORIUCHI M, MIYAMOTO A, SHIMIZU T: Lipopolysaccharide (LPS) inhibits steroid production in theca cells of bovine follicles in vitro: distinct effect of LPS on theca cell function in pre- and post-selection follicles. J Reprod Dev 60: 280-287, 2014a.

MAGATA F, HORIUCHI M, MIYAMOTO A, SHIMIZU T: Peptidoglycan inhibits progesterone and androstenedione production in bovine ovarian theca cells. Toxicol In Vitro 28: 961-967, 2014b. 
MARTINEAU M, PAPACLEOVOULOU G, ABU-HAYYEH S, DIXON PH, JI H, POWRIE R, LARSON L, CHIEN EK, WILLIAMSON C: Cholestatic pregnancy is associated with reduced placental $11 \beta \mathrm{HSD} 2$ expression. Placenta 35: 37-43, 2014.

MEIER Y, ZODAN T, LANG C, ZIMMERMANN R, KULLAK-UBLICK GA, MEIER PJ, STIEGER B, PAULIMAGNUS C: Increased susceptibility for intrahepatic cholestasis of pregnancy and contraceptive-induced cholestasis in carriers of the $1331 \mathrm{~T}>\mathrm{C}$ polymorphism in the bile salt export pump. World J Gastroenterol 14: $38-45,2008$.

MENG LJ, REYES H, AXELSON M, PALMA J, HERNANDEZ I, RIBALTA J, SJÖVALL J: Progesterone metabolites and bile acids in serum of patients with intrahepatic cholestasis of pregnancy: effect of ursodeoxycholic acid therapy. Hepatology 26: 1573-1579, 1997a.

MENG LJ, REYES H, PALMA J, HERNANDEZ I, RIBALTA J, SJÖVALL J: Effects of ursodeoxycholic acid on conjugated bile acids and progesterone metabolites in serum and urine of patients with intrahepatic cholestasis of pregnancy. J Hepatol 27: 1029-1040, 1997b.

MENG LJ, REYES H, PALMA J, HERNANDEZ I, RIBALTA J, SJÖVALL J: Profiles of bile acids and progesterone metabolites in the urine and serum of women with intrahepatic cholestasis of pregnancy. $J$ Hepatol 27: 346-357,1997c.

MILONA A, OWEN BM, COBBOLD JF, WILLEMSEN EC, COX IJ, BOUDJELAL M, CAIRNS W, SCHOONJANS K, TAYLOR-ROBINSON SD, KLOMP LW, PARKER MG, WHITE R, VAN MIL SW, WILLIAMSON C: Rised hepatic bile acid concentrations during pregnancy in mice are associated with reduced farnesoid $\mathrm{X}$ receptor function. Hepatology 52: 1341-1349, 2010.

PASCUAL MJ, SERRANO MA, EL-MIR MY, MACIAS RI, JIMÉNEZ F, MARIN JJ: Relationship between asymptomatic hypercholanaemia of pregnancy and progesterone metabolism. Clin Sci (Lond) 102: 587-593, 2002.

PUSL T, BEUERS U: Intrahepatic cholestasis of pregnancy. Orphanet J Rare Dis 2: 26, 2007.

REYES H: Sex hormones and bile acids in intrahepatic cholestasis of pregnancy. Hepatology 47: 376-379, 2008.

REYES H, SJOVALL J: Bile acids and progesterone metabolites in intrahepatic cholestasis of pregnancy. Ann Med 32: 94-106, 2000.

REYES H, BÁEZ ME, GONZÁLEZ MC, HERNÁNDEZ I, PALMA J, RIBALTA J, SANDOVAL L, ZAPATA R: Selenium, zinc and copper plasma levels in intrahepatic cholestasis of pregnancy, in normal pregnancies and in healthy individuals, in Chile. $J$ Hepatol 32: 542-549, 2000.

REYES H, ZAPATA R, HERNÁNDEZ I, GOTTELAND M, SANDOVAL L, JIRÓN MI, PALMA J, ALMUNA R, SILVA JJ: Is a leaky gut involved in the pathogenesis of intrahepatic cholestasis of pregnancy? Hepatology 43: 715-722, 2006.

RIBALTA J, REYES H, HERNÁNDEZ I, FUENTES O, BÁEZ M, GONZÁLEZ M, PALMA J: Can a selenium deficiency affect the pathogenesis of cholestasis in pregnancy? (in Spanish). Gastroenterol Hepatol 18: 114-120, 1995.

RIZZO G, RENGA B, MENCARELLI A, PELLICCIARI R, FIORUCCI S: Role of FXR in regulating bile acid homeostasis and relevance for human diseases. Curr Drug Targets Immune Endocr Metabol Disord 5: 289-303, 2005.

SONG X, VASILENKO A, CHEN Y, VALANEJAD L, VERMA R, YAN B, DENG R: Transcriptional dynamics of bile salt export pump during pregnancy: mechanisms and implications in intrahepatic cholestasis of pregnancy. Hepatology 60: 1993-2007, 2014.

ŠIMJÁK P, PAŘÍZEK A, VÍTEK L, ČERNÝ A, ADAMCOVÁ K, KOUCKÝ M, HILL M, DUŠKOVÁ M, STÁRKA L: Fetal complications of intrahepatic cholestasis of pregnancy. J Perinat Med 43: 133-139, 2015.

TREMELLEN K, SYEDI N, TAN S, PEARCE K: Metabolic endotoxaemia - a potential novel link between ovarian inflammation and impaired progesterone production. Gynecol Endocrinol 24: 1-4, 2014.

VALLEJO M, BRIZ O, SERRANO MA, MONTE MJ, MARIN JJ: Potential role of trans-inhibition of the bile salt export pump by progesterone metabolites in the etiopathogenesis of intrahepatic cholestasis of pregnancy. J Hepatol 44: 1150-1157, 2006. 
VONNAHME KA, NEVILLE TL, PERRY GA, REDMER DA, REYNOLDS LP, CATON JS: Maternal dietary intake alters organ mass and endocrine and metabolic profiles in pregnant ewe lambs. Anim Reprod Sci 141: 131-141, 2013.

WANG C, CHEN X, ZHOU SF, LI X: Impaired fetal adrenal function in intrahepatic cholestasis of pregnancy. Med Sci Monit 17: CR265-CR271, 2011. 